\title{
Material Transformations of Antique Sculpture in Contemporary Art
}

\author{
Bente Kiilerich
}

\begin{abstract}
In the twenty-first century, famous antique statues have been reinterpreted by artists of very different backgrounds. A characteristic feature of the contemporary artwork is the use of unconventional sculptural materials such as paper, soap, concrete, polycarbonate and metal cans. In the dialogue called the Cratylus, Socrates explains that images are far from possessing the same qualities as the originals they imitate' (432d). Socrates refers to the relationship between an image (eikon) and its buman model, but much the same can be said about the relationship between the new images and their ancient art-historical models. Aristotle holds that matter (hyle) is separate from form (eidos). In the contemporary works, the matter is changed - e.g. from marble to bydrostone or from bronze to concrete - but the form is preserved. The antique statue is the underlying thing (Aristotle's hypokeimenon) that persists through the material changes. The article presents some of the ways that European, Asian and American artists, in the second decade of the twenty-first century, transform the appearance of renowned antique statues.
\end{abstract}

Keywords: antique sculpture, sculptural materials, materiality, reception of the antique in the twenty-first century, contemporary sculpture

\section{Introduction}

The twenty-first century has witnessed a recurring fascination with antiquity and a continual interest in revisiting famous antique works of art. Within the last decade, the Apollo Belvedere, the Belvedere torso, the Capitoline Venus, the Discobolus, the Doryphoros, the Heracles Farnese, the Laocoon, the Nike of Samothrace, Praxiteles' Hermes, the Riace bronzes, the Venus de Milo and many other antique statues have been reinterpreted and presented in novel guise. ${ }^{1}$ With a few exceptions, the sculptures that are singled out are paradigmatic works that belong to the classical kanon, or which, like the sculptures displayed in the Belvedere collection, have come to fame through their particular life history. Still others, such as the Riace bronzes, which were found at the bottom of the sea, have acquired fame through their specific find circumstances. The male figures favoured for reinterpretation are handsome youths (foremost Apollo and Hermes) and paragons of physical strength (Heracles, the Riace bronzes) and athletic prowess (Discobolos, Doryphoros). The female figures are models of physical beauty and erotic appeal. Like the male figures,

${ }^{1}$ Besnard 2018, 2019a, 2019b; Kiilerich 2018, 2019, 2021; Squire 2018. 
they are mostly unclothed or with the body partially revealed, like the Venus de Milo, who is the most popular of all. ${ }^{2}$

In the hands of contemporary artists from very different backgrounds and very different geographical regions the ancient marble and bronze statues appear totally transformed - and yet they are still fully recognizable. In the exchange between classical and contemporary art, the ancient form remains the same, while the physical matter in which it is created changes. In fact, a distinguishing feature of the contemporary works that recreate and reinterpret classical sculpture is the choice of unusual and unexpected physical matter and the unorthodox combinations of a variety of substances.

\section{The conventional materials of sculpture}

In his survey of the materials of sculpture, Nicholas Penny distinguishes between hard stones, granite and porphyry, white marbles and alabasters, coloured marbles, schist, sandstone and limestone, wood, ivory and horn, clay, stucco, wax and bronze and other copper alloys. ${ }^{3}$ These are what we may refer to as the conventional materials that artists have used for centuries for small and large-scale plastic and glyptic works both in Europe and elsewhere. Many of these substances were also employed in antiquity.

The primary materials of Greek sculpture were marble and bronze. Archaic Greek sculpture was in marble or, in the absence of marble, limestone and sandstone. From the early fifth century onwards bronze became increasingly important for life-size statues. Stone and metal have different qualities: while both male and female figures could be represented in any one of these, the Artemision Zeus with outstretched arms was easier to fashion in bronze than in marble; what is more, the tanned finish of bronze was particularly well suited for representations of athletic men and gods in the nude. For a female figure, polychrome marble gave the best impression of soft skin and thin garments. In addition to marble and bronze, three-dimensional works were carved in wood, as in the archaic xoana, or made in a coroplastic technique (clay, terracotta); sculptors could also combine different materials for acroliths, with the body carved from wood, and the face and hands made of marble, thus reserving the more expensive substances for the more important parts. ${ }^{4}$ Given that the bodies of cult statues were sometimes dressed in real clothes, the torso did not need to be made of the same material as the uncovered parts. ${ }^{5}$ Ivory and gold were employed for chryselephantine sculptures, at first on a small scale, and subsequently also for cult images of colossal size. The sources confirm that Phidias' chryselephantine statues of Athena Parthenos and the

2 For the life history of the Venus de Milo, see Jockey 2011; for her impact on art after 1820, see Cuzin et al. 2000, 430-499; Salmon 2000; Kiilerich 2012.

${ }^{3}$ Penny 1993.

${ }^{4}$ See, e.g. Despinis 1975; Meiggs 1982, 300-324: wood for sculpture; Lapatin 2001; Witcombe 2018, 54-61.

${ }^{5}$ Steiner 2001, 109-110; Witcombe 2018, 90-95. 
Olympic Zeus included semi-precious stone, polychrome marble and bronze (Paus. 1.24.5-7; 5.11.1-9). The brilliance of gold and other rich substances conveyed an impression of the divinities' radiant appearance.

In the Roman period, a transformation took place as bronze statues, by Myron, Polycleitus, Lysippus and others, were replicated in marble and other stone. Thus, many 'new-look' Doryphoroi came into existence when, instead of burnished bronze, the statue was carved in white marble and even in black basalt. Translated from the Greek to the Roman, the Doryphoroi also acquired new meanings in their new settings. ${ }^{6}$ By creating sculptures from coloured and variegated stone to a larger extent than done by the Greeks, who preferred to add paint to white marble, the Romans extended the range of core materials. They incorporated stone of different colours within a single work, e.g. a head of one stone combined with a body in another, and they contrasted light and dark stone in multi-figured compositions. ${ }^{7}$ Such use of multiple substances is worth having in mind when approaching the varied materials encountered in present-day works.

\section{The unconventional materials of contemporary sculpture}

While the materials used in antiquity for statues and reliefs were limited, at least by modern standards, contemporary sculpture can be made from any material, durable or ephemeral, expensive or cheap. ${ }^{8}$ In addition to conventional bronze, stone and wood, artists use steel, aluminium, iron, glass, rubber, vinyl, plastic film, gravel, earth, light bulbs and electric wires, often combining several substances in a single work. ${ }^{9}$ In some instances, the main point is not the actual material as such but the effects that can be achieved in the interplay of physical matter and visual appearance, with one material taking on the appearance of another.

Some contemporary artists create works that superficially mimic antique sculpture. ${ }^{10}$ One example is Li Hongbo's Apollo Belvedere bust from 2014. It may look like marble but it is made from paper in a conventional Chinese technique that requires much skill. For the bust, Li Hongbo (b. 1974, Jilin) layered thousands of thin white paper sheets, attaching each sheet with glue at special points to create a honeycomb pattern. He then cut out the raw form with a saw and shaped it using scissors before polishing with sandpaper. The Apollo bust looks solid, but the intriguing aspect is that it can be stretched and expanded like an accordion. ${ }^{11}$

\footnotetext{
${ }^{6}$ See, e.g. Marvin 1997, and in general, Perry 2005.

7 See, e.g. Anderson 1989; De Nuccio \& Ungaro 2002; Allen 2015, 157-165.

${ }^{8}$ Harper and Moyer (eds) 2006; Farag 2020.

${ }^{9}$ Harper and Moyer (eds) 2008 present numerous examples of the variety of materials for sculpture in outdoor settings.

${ }^{10}$ Due to copyright restrictions and high reproduction fees, photographs of all the works under discussion are not reproduced here. However, the relevant images can easily be found on the internet, e.g. by inserting the name of the artist in a google images search.

11 https://theculturetrip.com/asia/china/articles/li-hongbo- accessed 20 April 2018]; Kiilerich 2019, 109.
} 


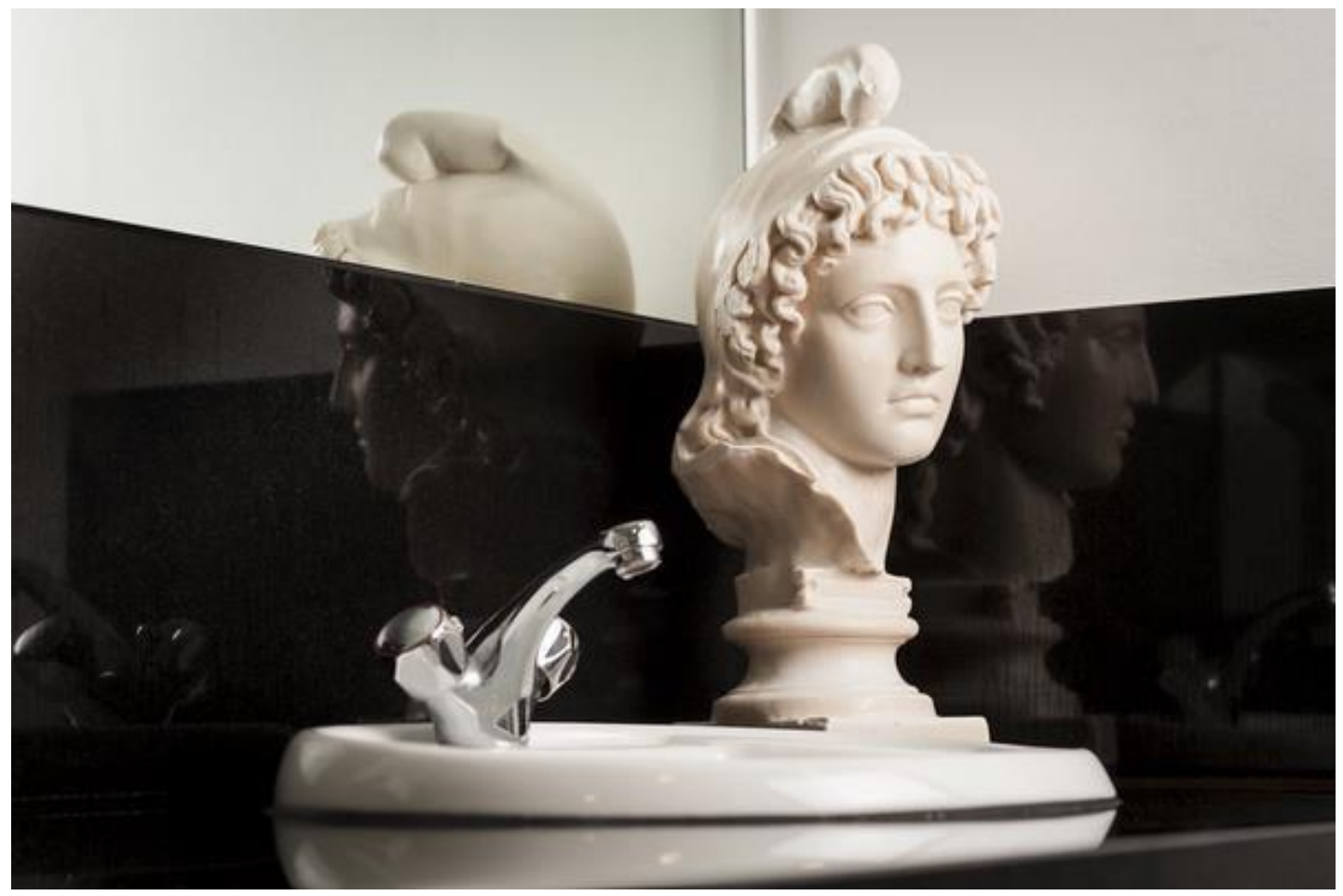

Fig. 1 Meekyoung Shin, Head of Attis. Toilet project, 2013, soap, fragrance.

Photograph: Jim Varney, YSPsculpture, licensed under Creative Commons CC BY-ND.

Li Hongbo has employed the same technique for Roman portrait busts and smallscale replicas of the Laocoon and the Nike of Samothrace. The latter images call to mind the popular plaster casts of renowned artworks for sale in tourist shops, only by contrast to those mass-produced objects Li Hongbo's works are handmade. ${ }^{12}$

Viewing the statues of the artist Meekyoung Shin (b. 1967, South Korea), one might also be fooled into seeing Greek marble statues. But the figures in the Translation series, the Weathering project: Kouros, 2009-ongoing, the Toilet project, 2013, and the Ruinscape series from 2018 are made from soap, when necessary supported by a skeleton of metal and wood. ${ }^{13}$ The soap sculptures in the Toilet project could actually be used for washing hands and thus were subject to gradual disintegration (Fig. 1). Shin makes accurate to scale copies of Attic kouroi and korai, sometimes even reconstructing their lost polychromy. To mimic bronze, a soap figure may be covered in a layer of oxidized copper. She plays with the medium, in one version giving the marble Aristodikos a bronzed look, in another version applying the distinctive green colour suggestive of patinated bronze. Placed on bases and lined up

12 Yi Zhang Zhi 2014.

13 Besnard 2019b; Hughes 2020. 
next to one another, the images provide the illusion of being objects in an archaeological museum. Whereas marble statues usually have no smell, the scent of the perfumed soap brings to mind that antique statues were sometimes rubbed in fragrant, perfumed oil; in fact, smell was an important part of ancient aesthetics that is easily overlooked. ${ }^{14}$

While the surfaces of Meekyoung Shin's sculptures are smooth and soft, a rough and rugged appearance characterises works in concrete by the American sculptor Tony Matelli (b. 1971, Chicago). He is known for his hyperrealistic sculptures of animals and human beings, most famously Sleepwalker, often shown in absurd situations. ${ }^{15}$ Matelli has recently turned to the classical repertoire, presenting works in cast concrete with accessories in painted bronze. The items are fabricated from commercially produced concrete sculptures with the coarse-grained material laid bare by means of sandblasting: Warrior (Riace A), 2015, sports a variety of mock sausages. One Apollo Belvedere bust displays painted bronze bananas and orange slices, another has succulent mandarins and strawberries, while concrete busts of Praxiteles' Hermes are decorated with slices of watermelon or apples (all work 2018). Watermelons, similarly, are the attributes of Hera (balf). In these clever imitations of fruit, we are fooled into believing the painted bronze items to be real fruit. The substances present an inverted hierarchy: the divinities are made from cheap material, whereas the everyday object - fruit - is fashioned in bronze. One may compare the various versions of Pistoletto's Venere degli stracci: in the Venus of the rags, the 'cheap' clothes in the heap is an equally important part of the artwork as the Venus, disregarding whether the latter is fashioned in marble, plaster or polystyrene. ${ }^{16}$

Polystyrene and other synthetic materials have proved especially important for the works of contemporary sculptors. These substances are generally strong and easily moulded and therefore suited for a variety of visual expressions. ${ }^{17}$ Moreover, in comparison with marble and bronze, they are cheap and readily available on the market. The Hercules (Farnese), 2014, by British artist Mathew Darbyshire (b. 1977, Cambridge) is fashioned from layers of white polystyrene. ${ }^{18}$ The heavy-weight Hercules is thus presented in light-weight material; from a distance the polystyrene mimics the appearance of white marble to a larger extent than does the weathered surface of the antique sculpture discovered in the Baths of Caracalla. Presenting the sculpture signed by Glykon of Athens in this novel form, the artist stresses 'the nice element of subversion in a sacred marble form being translated in to the most debased and abundant material. [...] Although it is grim stuff, it has that pristine

${ }^{14}$ Classen et al. 1994; Brun 2000.

15 See, e.g. Dinesen et al. 2012; Matelli 2015. For hyperrealism, see Letze \& Fritz 2018.

16 Kiilerich 2015; Minnucci 2020.

${ }^{17}$ Polystyrene, invented in 1938 , is a synthetic hydrocarbon polymer. It can be solid or foamed. Expanded polystyrene foam, also known as styrofoam, is very light, and is therefore used for packaging and insulation.

${ }^{18}$ Fortenberry \& Morrill 2018, 172-173; Vout 2018, 223. 


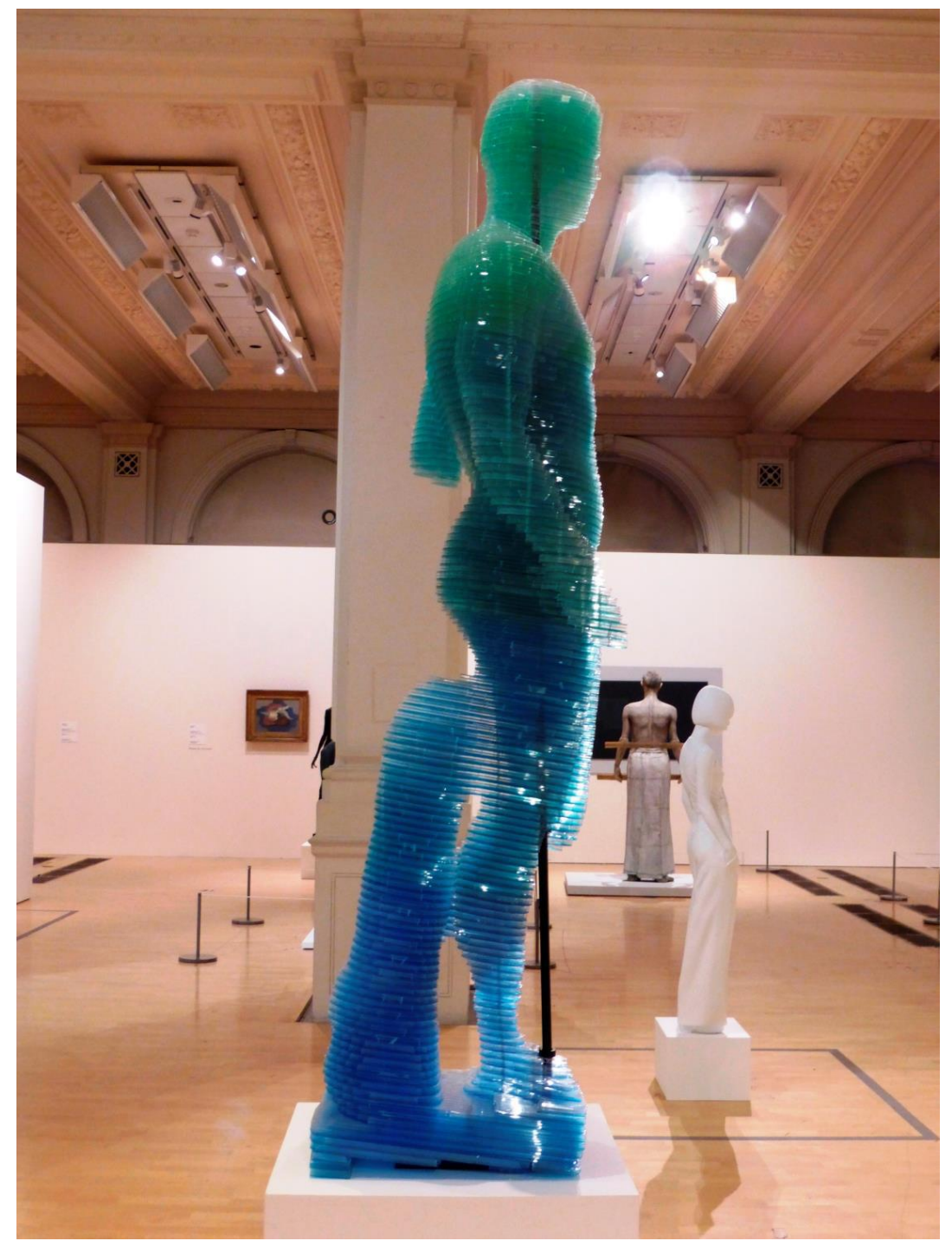

Fig. 2 Mathew Darbyshire. CAPTCHA no. 11-Doryphoros, 2014, multiwall polycarbonate. Photograph: Carolyn Gifford, flickr.com, licensed under Creative Commons CC BY 2.0.

whiteness and a reflective shimmer to rival marble. ${ }^{19}$ By contrast, colour is the catchword of Darbyshire's CAPTCHA series, similarly from 2014, which renders several famous sculptures, e.g. the Venus de Milo and the Belvedere torso, in horizontally layered coloured multiwall polycarbonate. ${ }^{20}$ CAPTCHA no. $11-$ Doryphoros is made of multiwall polycarbonate, silicone and steel armature (Fig. 2). ${ }^{21}$ The saturated colours are partly transparent, making the sculptures appear as if

${ }_{19}$ Cahill 2014, interview with the artist.

20 Polycarbonates (PC) are thermoplastic polymers containing carbonate. Some are transparent.

21 Vout 2018, 222-224. 
lighted from within. In other works, the artist combines various other substances: for Brand Deity: Nike, a $2.5 \mathrm{~m}$ version of the Nike of Samothrace exhibited in Selfridges department store in Birmingham in 2019, Darbyshire uses cast metal on a steel armature, epoxy and pigments to create a layered, light blue, shimmering surface. The work is part of the multi-coloured Brand Deities series, 2018, for the Yorkshire Sculpture Park, which includes Venus, Mars and, appropriately, Hermes, the god of trade. The British artist claims that brands are the new deities and department stores the new temples.

The commodification of art and the mixture of high art and commercial culture come to the fore in sculptures by the French artist Alben (b. 1973, Bordeaux) in which products ranging from metal cans to toys and sweets are cast in synthetic resin. ${ }^{22}$ Working in the tradition of Arman and pop art, Alben recreates the Venus de Milo and the Nike of Samothrace in reduced scale. The physical objects encapsulated in the resin give each sculpture its particular visual appearance: Venus de Milo Tide, from 2013, is a patchwork of Tide-washing powder and other colourful, commercial products; Venus Coke consists of crushed Coca-Cola metal cans; Venus de Milo Perrier is made of Perrier bottles set in resin; Venus de Milo Delft bleu is composed of broken pieces of porcelain and resin (all from 2014). ${ }^{23}$ A spectacular version is the Venus de Milo Barbie $(1.15 \mathrm{~m})$ : the upper naked part contains naked dolls, while the lower draped part shows clothed dolls and clothing. Ironically, perhaps, the antique symbol of beauty is here interacting with a modern female stereotype. ${ }^{24}$ Turning to another Louvre masterpiece, the Victoire de Samothrace Tsing Tao consists of Chinese beer cans while the Samothrace Mexican snacks $(0.9 \mathrm{~m})$ contains potato chip paper, while the Victoire de Samothrace McDonald, $2014(0.9 \mathrm{~m})$ is made up of red French fries sleeves. In the various versions we immediately recognise the famous model that lies behind; still, Alben's unconventional substances transform the models into markedly different works. The reduced scale of the antique models seen through the eyes of contemporary consumerism negates the monumental aspect of the originals. Most immediate visually, instead of the current white marble of the ancient (originally polychrome) statues, the matter set in the resin provides a vivid colouring to the surfaces.

\section{Penetrating the surface}

Colour is equally important in the art of Fabio Viale (b. 1975, Cuneo), an Italian artist who follows the ancient tradition of sculpting in marble, a material he employs with great dexterity to represent subjects ranging from everyday objects - such as a rubber tyre fashioned from black marble - to ancient sculpture. ${ }^{25}$ However, after

\footnotetext{
${ }^{22}$ Resin sculpture is cast using synthetic fiberglass resin, a liquid substance that hardens to a solid form. It can be painted to mimic other materials such as marble.

${ }^{23}$ For some of Alben's work at the Accumulation exhibition in New York in 2014, see Hayward 2014.

${ }^{24}$ For the impact of Barbie from 1959 onwards, see D'Amato 2009.

${ }^{25}$ Gagliardi (ed.) 2018.
} 


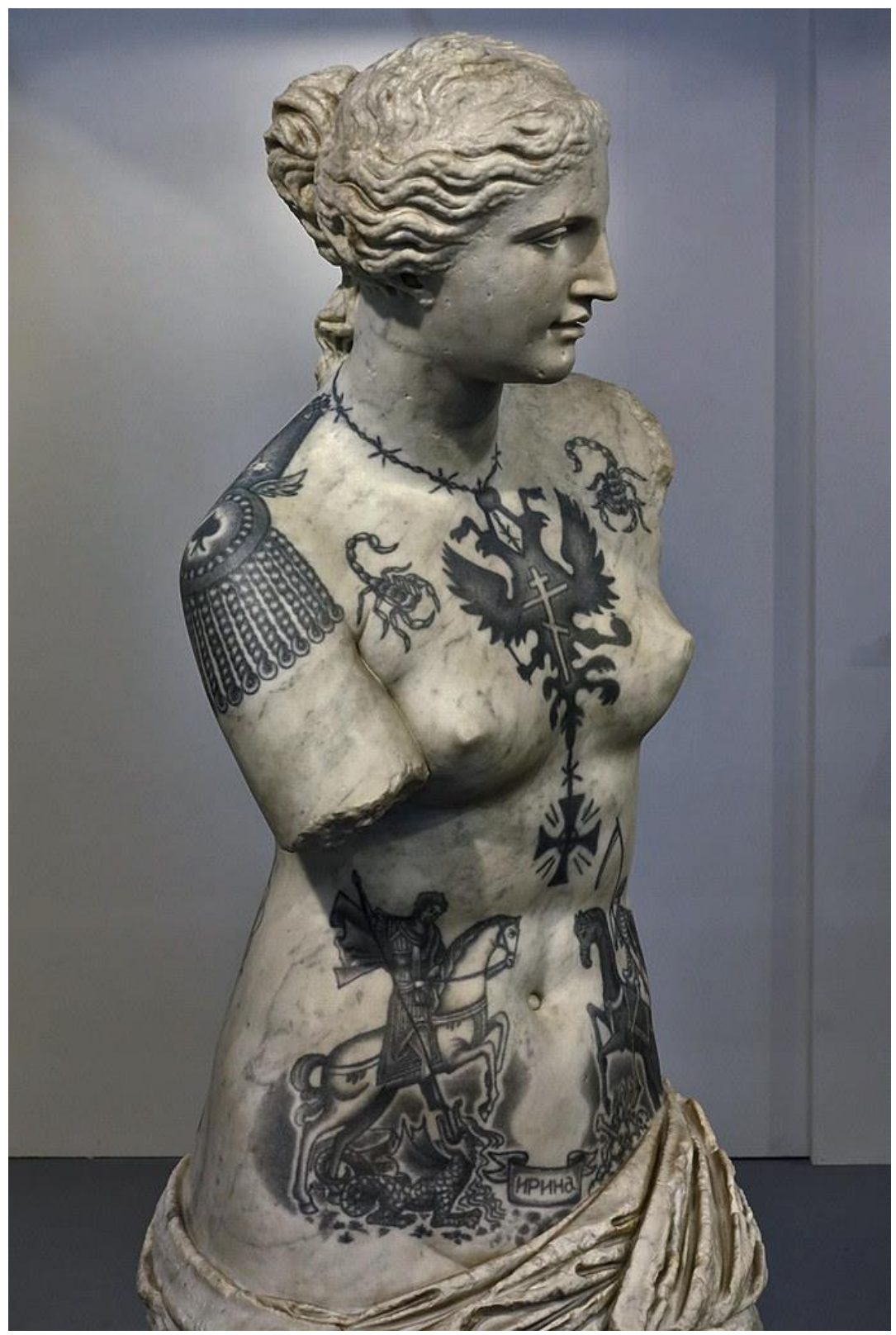

Fig. 3 Fabio Viale. Venus, 2017, marble, ink. Photograph: Luigi Tiriticco, 'Arte Fiera 18070', flickr.com, licensed under CC BY 2.0.

having carved the classical models in marble, he often changes their appearance by means of paint. By allowing colour to penetrate the marble skins, he makes the sculptures look as if they were covered in tattoos. The repertoire includes traditional Japanese yakuza full body designs and chest panel tattoos. Among the motifs are dragons, mythological imagery and criminal codes. In one work, the back of a Venus de Milo replica is totally covered in red, blue and black swirling floral designs of Japanese inspiration; in another, the tattoos including warrior saints are confined to 
bluish black (Fig. 3). Canova's Venere Italica, 2015, is tattooed with Japanese-style blue fish and waves. Laocoon's tattoos - in this instance the motif is taken from Giovanni da Modena's Inferno painting in Bologna, 1410 - cover part of his body as if it were a close-fitting body suit reaching to his knees. ${ }^{26}$ Michelangelo famously admired the Belvedere torso; Viale now projects figures from Michelangelo's Sistine chapel frescoes onto the torso Kouros from 2015, unifying the ancient, the modern, i.e. Renaissance and the contemporary. The quality of the carving at times makes grey-veined marble allude to slightly dirty plaster casts, while the surface treatment of the white marble in Nike, 2017 - a reduced version of the goddess from Samothrace, and Door Release, 2018 - a life size rendering of the hand of Constantine in the Capitoline museum - gives the illusion of being made from styrofoam. ${ }^{27}$

While most artists are concerned with surface finish and exterior appearance, some artists explore the potential interior of statues. If a statue is imagined to have the physical appearance of a divinity, what may the anthropomorphic gods and goddesses be imagined to look like on the inside? Speaking of the insides of chryselephantine sculptures, in the second century Lucian refers to 'a tangle of bars and struts and nails driven right through, and beams and wedges and pitch and clay', a marked contrast to the exuberant exterior. ${ }^{28}$ In Classic Sculptures Dissected, 2011-12, Chinese artist Cao Hui (b. 1968, Beijing) visualises the Venus de Milo to possess a human interior. He penetrates the surface by slicing up the figure into horizontal cross sections, each presenting a mock anatomy in resin, fibre glass and acrylic paint. Venus' resin body contains a simulation of flesh and intestines with cross sections of the various organs thus creating a kind of 'anatomical Venus'. ${ }^{29}$ By slicing up the body of the Venus, and, in other works, by cutting a large head of Michelangelo's David in slices and dividing another one into large chunks, Cao lays bare their interiors. These works that can be disassembled and assembled are somewhat grotesque, and as the raw interior contrasts with the smooth and flawless exterior, they question the canon of beauty, perfection and harmony.

A more poetic interpretation of potential internal substances is proposed by the American Daniel Arsham (b. 1980, Cleveland), an artist who works across the disciplines of sculpture, painting, film and design, most recently collaborating with Dior. In 2015 he fashioned the Fictional Archaeology series, depicting fragmentary figures in volcanic ash that looked as if they were in a state of decay. ${ }^{30}$ For sculptures from 2019, presented at the 'Paris 3020' exhibition in spring 2020, Arsham used hydrostone in combination with blue calcite and pink quartz. ${ }^{31}$ The artist took moulds of plaster casts of divinities and historical figures in the atelier of the

\footnotetext{
${ }^{26}$ www.fabioviale.it; Gagliardi (ed.) 2018, figs. on pp. 79-85 (Laocoon); Neira 2020.

${ }^{27}$ Gagliardi 2018, figs. on p. 31 and 33: Door Release; pp. 60-63: Nike.

${ }^{28}$ Cited by Steiner 2001, 120. See in general Steiner 2001, 120-134.

${ }^{29}$ Noorata 2013. The 'anatomical Venus' was created by Clemente Susini around 1780 to teach anatomy, see Ebenstein 2016.

${ }^{30}$ Arsham 2016.

${ }^{31}$ https://moussemagazine.it/daniel-arsham-paris-3020-at-Perrotin-paris-3020/
} 
Réunion des Musées Nationaux at the Grand Palais, Paris. After having cast the statues in hydrostone, erosions were chiselled into them and clusters of crystal placed in the cavities, making it look as if the white, grey or black exterior concealed a sparkling blue or pink crystalized interior. Eroded Venus of Milo in hydrostone includes respectively blue calcite in one work, pink quartz in another, embedded in the head and at the points where the arms are broken off. ${ }^{32}$ This material combination evokes the idea of a secret mineral interior hidden under the surface. In his (at time of writing) latest exhibition: 'Time Dilation', Perrotin Gallery, New York (16 January 2021 - 20 February 2021), Arsham presents further works that explore mineral materiality, e.g. Amethyst Eroded Bust of Lucius Verus, 2020, Blue Calcite Eroded Ariadne Sleeping, 2020. Arsham calls his works 'future relics of the present' projected into the future time of 3021. The artist explores the concept of time and poses the possibilities that the images are either falling apart, or, given that crystals form over time, are growing into new forms. ${ }^{33}$

\section{Between past and present}

Made from paper, soap, concrete, polystyrene, reused metal cans, hydrostone and other matter, ancient artworks (re)appear as new in the twenty-first century. These material strategies preserve the ancient models, while simultaneously turning them into something completely different. Although the themes are classical, the artistic approaches are quite unclassical. Indeed, despite the repeated references to ancient sculpture, none of the above-mentioned artists are 'classicists' in the sense of aiming for contemporary versions of the classical or neoclassical style.

It is worth recalling that antique references present but one aspect of these sculptors' outputs. Their repertoires embrace a variety of themes, often focused on domestic objects and trivial subjects: Cao Hui's dissections, for instance, include armchairs and leather clothes. ${ }^{34}$ Meekyoung Shin produces soap sculptures of glass and ceramic vases, while Li Hongbo sculpts colourful flowers that unexpectedly turn into guns. Tony Matelli, who usually works in the hyperrealistic style, has fashioned a surprisingly lifelike dog and sculptures of monkeys, fruit and flowers. ${ }^{35}$ Fabio Viale presents sculptures of large rubber tyres that are actually made from black marble. ${ }^{36}$ Among other endeavours Viale has launched a marble boat on the River Po. ${ }^{37}$ Matthew Darbyshire's Bureau from 2014 consists of installations with furniture and sculptures of cats placed next to the Styrofoam Hercules. Speaking about the ancient sculptures, the artist states that: 'My work uses easily recognisable symbols [...] and I use them much the same way as I might use a water cooler to epitomise cleanliness;

\footnotetext{
${ }^{32}$ Hydrostone is a hard gypsum cement. Blue calcite is a rare, mottled blue calcium carbonate; rose quartz is a hard silicone dioxide.

33 Ebert 2020. Review of the exhibition in the New York Times and videos on YouTube.

34 Jungbauer 2015.

35 Dinesen et al. 2012.

36 Gagliardi 2018, 46 (Ruota cinese, 2010), 47 (Earth, 2017), 55 (Infinito, 2017).

37 Gagliardi 2018, 98-99.
} 
a cat, domesticity; or a vacuum-cleaner, technology'. ${ }^{38}$ Modern devices are likewise among Daniel Arsham's sculpted works - a camera, a telephone, a radio and cars in states of decay. At times classical and modern subjects are presented side by side, as in Arsham's 2021 exhibition of eroded versions of Pokemon figures along with his eroded antiques. The artist suggests that in a thousand years, the Pokemons will be antiquities just like the Venuses. ${ }^{39}$ The artistic transformations thus apply to everyday objects as well as to ancient sculptures.

\section{Accidental and deliberate material transformations}

Accidental material transformation is a natural part of the historical process of ruin and decay and characteristic of archaeological artefacts. The majority of the extant ancient artworks are fragmentary: Some, like the Venus de Milo, are missing limbs, others, like the Belvedere torso, survive merely as a torso, while still others are preserved only as a head or another body part. By now, the ancient artworks have become archaeological artefacts, open for reconstructions. Even without missing parts, most ancient statues have lost the accessories that served to identify them, the polychrome marble statues have lost their colour over time and the burnished bronzes have changed the appearance of their skin through the patina of the years gone by. ${ }^{40}$ Thus, the original surfaces and the original finishes have been effaced by time. Trying to reconstruct the lost polychromy, one often - whether as archaeologist or art historian - comes to reconstruct an unoriginal polychromy that presumably bears only a passing resemblance to that of the antique model. When contemporary artists turn to the very same art works and provide them with new colour, they obviously do not pretend to recreate the original look; rather they take their point of departure in the 'natural' transformations of the sculptures, presenting deliberate artistic transformations that swing to and fro between the white and the coloured, the simple and the complex, the likely and the unlikely.

At times the material transformations are considerable, visually setting the modern work apart from its ancient model as in Alben's pop art Nikai and Venuses. Sometimes the new work approximates the material of the old, but even then the material often turns out to be something other than what it appears to be, one substance presenting itself in the guise of another: From a distance Li Hongbo's paper sculptures may look like marble; Viale's marble may look like styrofoam, while Darbyshire's styrofoam may look like marble. In effect, one substance may imitate another and even imitate a substitute for another: thus Meekyoung Shin's Aristodikos kouros presents a bronze version of the marble statue - in soap. The artists thus play on materiality, simulation and the notions of what an image is and what it seems to be, a question addressed already by Plato.

\footnotetext{
38 Vout 2018, 223.

${ }^{39}$ Laster 2021.

${ }^{40}$ For antique polychromy, see Brøns \& Hedegaard 2019; and the articles in CLARA special issue no. 1 , vol. $5,2020$.
} 


\section{Cratylus and the qualities of images}

Plato's dialogue called the Cratylus concerns the correctness of names, the relationship between names and things, between a word and its designation. ${ }^{41}$ At some point in the long conversation between Cratylus and Socrates, the qualities of images and the relationship between image and model enter the discussion. It is worth quoting the passage in full, as it is of some interest to the current discussion of contemporary transformations of ancient art. Socrates states:

The image (eikon) must not by any means reproduce all the qualities of that which it imitates, if it is to be an image [...]. Would there be two things, Cratylus and the image of Cratylus, if some god should not merely imitate your colour and form, as painters do, but should also make all the inner parts like yours, should reproduce the same flexibility and warmth, should put into them motion, life, and intellect, such as exist in you, and in short should place beside you a duplicate of all your qualities. Would there be in such an event Cratylus and an image of Cratylus, or two Cratyluses? $(432 \mathrm{~b}-\mathrm{c})$.

When Cratylus concedes that in that event there would be two Cratyluses, Socrates continues about the correctness of images that we must not insist that they are no longer images if anything is wanting or added. This is due to the fact that an image is only like the model in some aspects, but not in all (e.g. marble versus flesh and bone). 'Do you not perceive how far images are from possessing the same qualities as the originals which they imitate?' (432d). Even the 'flesh sculptures' of Cao purporting to reflect an interior 'reality' obviously do not propose to recreate the inner being but merely plays with the notions of realism in art.

Using the example of a shuttle, Socrates explains what all shuttles share with the model: 'they all contain the form/ideal (eidos) of the model' (389b-c).$^{42}$ They may differ in size and other features depending on whether the model, in casu the shuttle, is to be used for a heavy or light garment, but the shuttle eidos must be preserved. It is tempting to transfer this idea to the relationship between the contemporary works and the paradigmatic statues: the contemporary works differ in many respects from the model, but they all contain the eidos of the model. We recognise the Apollo, the Venus and the Nike at the core of the new works: the new and the ancient works differ in virtue of their matter but they are basically the same in form.

41 Plato. Cratylus. Parmenides. Greater Hippias. Lesser Hippias, with an English transl. by H.N. Fowler, LCL, London 1963, 6-191. See also Steiner 2001, 68-74.

42 The fact that the word eidos can mean both the form and the idea or the ideal or immanent form makes it difficult to render the precise implication of the term. 


\section{Form versus matter}

Aristotle holds that a physical object is a compound of matter and form. ${ }^{43}$ A morphe consists of byle (material) and eidos (form). The morphe of the artwork presents a form/eidos by means of a given material/byle. Aristotle provides the example of a circle which may be in bronze and stone and wood, but the materials are not part of the essential substance of the circle, because the circle is separate from them. Whether it is made of one material or another, it remains a circle, its matter being separate from its form (Metaphysics, 1036a 32-34). The circle eidos is the bypokeimenon, the 'underlying thing' or essence that persists through the material changes (cf. Arist. Phys. I, 190a-b). On the subject of statues, Aristotle notes that 'bronze is part of the statue as a concrete whole (synolos), but not of the statue in the sense of form (eidos)' (1035a 6-8)..$^{44}$ We refer to antique statues as, for instance, the Riace bronzes. But if we separate form and matter, it is apparent that the bronze although this is the material the ancient artist used for these two particular works - is not necessarily a constituent part of the Riace warriors. Form and matter are separate entities.

This has implications for the contemporary works in which the eidos of the ancient model is preserved but the material is changed. For example, Tony Matelli's Warrior (Riace A) is fashioned in coarse-grained concrete instead of the original's bronze. The eidos of the Doryphoros, first made in bronze by Polykleitos, is preserved in the marble versions made by Roman sculptors - and in the polycarbonate version by Mathew Darbyshire. The Venus de Milo may serve as another example: Darbyshire fashions the statue from multiwall polycarbonate; Alben fills resin moulds with crushed metal cans, dolls and porcelain; while Viale tattoos the marble surface. Applying the dichotomy of form and matter to the contemporary artworks, the ancient statue is the basic essence, the underlying thing (bypokeimenon) that persists through the material change.

\section{Conclusion}

In the early twenty-first century, the ancient artwork may be remade in durable concrete, ephemeral soap, food-stuff and even more unconventional substances. Contemporary sculptors explore the potentials of their chosen materials, a surface at times appearing as something other than what it actually is: a work that from a distance appears to be made of a solid material, close-up turns out to be made of paper, plaster or polystyrene. In the hands of the contemporary artists, the classical forms are repeated, often even at the proper scale and faithful to the general appearance of the antique image. The eidos, form or idea, of the ancient work lies at the core persisting through the material changes. But far from being accurate

${ }^{43}$ For Aristotle's hylomorphism, see e.g. Ainsworth 2020 with vast bibliography.

${ }^{44}$ Aristotle XVII (LCL 271), Metaphysics Books I-IX, with an English translation by Hugh

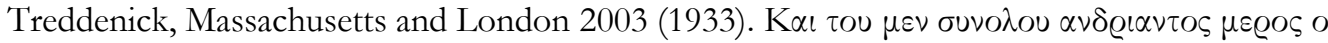

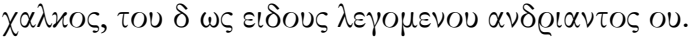


imitations, the mode, manner and means are different. Thus, although many new works are similar in form to the ancient models, they are different in virtue of their material. As Plato put it in the Cratylus, 'an image can never be identical to that of which it is an image'. The fact that artists of very different backgrounds and working in quite different styles continue to find new ways of revisiting the ancient images whether in a reverential, distanced, critical or ironic manner - shows that these 'iconic' works have come to be regarded as timeless exemplars of ideal form.

Prof. Bente Kiilerich

Dept of Linguistic, literary and aesthetic studies

University of Bergen

bente.kiilerich@uib.no 


\section{References}

Ainsworth, Th. 2020: 'Form vs. Matter', The Stanford Encyclopedia of Philosophy, https://plato.stanford.edu/archives/sum2020/entries/form-matter/ (accessed 2 March 2021).

Allen, M. 2015: 'Technique and Message in Roman Art', in B. Borg (ed.), A Companion to Roman Art, 157-165. Chichester: John Wiley \& Sons.

Anderson, M. L. (ed.) 1989: Radiance in Stone: Sculptures in Colored Marble from the Museo Nazionale Romano. Rome: De Luca.

Arsham, D. 2016: Fictional Archaeologies. Paris: Éditions Dilecta.

Besnard, T. A. 2018: 'L'empire des citations: vers un art contemporain "néonéoclassique"? in Antiquipop: La référence à l'antiquité dans la culture populaire contemporaine. Lyon: MOM Éditions https://books.openedition.org/momeditions/3335 (accessed 15 February 2021).

Besnard, T. A. 2019a: Du Weathering Project aux autoportraits en Venus: les sculptures onctueuses et savonneuses de Meekyoung Shin', in Anabases. Traditions et Réceptions de l'Antiquité 29: 71-86.

Besnard, T. A. 2019b: '(In)citations antiques. Les références à l'antiquité grecque et romaine dans l'art actuel', in: M. Scapin \& T.A. Besnard, Age of Classics. L'antiquité dans la culture pop, 178-207. Toulouse: Musée Saint-Raymond.

Brun, J.-P. 2000: 'The Production of Perfumes in Antiquity: The Cases of Delos and Paestum', AJA 104 (2): 277-308.

Brøns, C. \& Buccarella Hedegaard, S. 2019: 'Lost in Translation: An Introduction to the Challenging Task of Communicating Long-lost Polychromy on Graeco-Roman Marble Sculptures', Analecta Romana XLIV: 7-28.

Cahill, J. 2014: 'Deliberate Clichés: An Interview with Mathew Darbyshire' https://www.apollo.magazine.com/interview-mathew-darbyshire (accessed 9 March 2021).

Classen, C., Howes, D. \& Synnott, A. 1994: Aroma. The Cultural History of Smell. London \& New York: Routledge. 
Cuzin, J.-P., Gaborit, J.-R. \& Pasquier, A. (eds) 2000: D'après l'Antique. Paris: Musée du Louvre.

D'Amato, J. 2009: Barbie Running Press.

De Nuccio, M. \& Ungaro, L. (eds): I marmi colorati della Roma imperiale. Venice: Marsilio.

Despinis, G. 1975: Akrolitha (Archaiologikon Deltion, suppl. 21). Athens: Archaeological Society.

Dinesen, P. T., Frydenberg, E. \& Sørensen J. E. 2012: Tony Matelli- A Human Echo. Manchester: Cornerhouse Publishing.

Ebenstein, J. 2016: The Anatomical Venus. London: Thames \& Hudson.

Ebert, G. 2020: 'Eroded Replicas of Iconic Sculptures reveal Crystal Formations in new Sculptures by Daniel Arsham', Colossal 5. January 2020 https://thisiscolossal.com/2020/01/crystal-sculptures-daniel-arsham (accessed 12 March 2021).

Farag, M. M. 2020: Materials and Processes of Contemporary Sculpture. Cambridge: Cambridge Scholars Publishing.

Fortenberry, D. \& Morrill, R. 2018: Flying too close to the Sun. Myths in Art from Classical to Contemporary. London: Phaidon.

Gagliardi, P. (ed.) 2018: Fabio Viale. Fifteen. Catalogo della mostra, Torino 3. novembre 2018 - 12. Gennaio 2019. Poggiobonsi (Sienna): Cambi Editore.

Harper, G. \& Moyer, T. (eds) 2006: A Sculpture Reader: Contemporary Sculpture Since 1980. Hamilton: International Sculpture Center.

Harper, G. \& Moyer, T. (eds) 2008: Landscapes for Art: Contemporary Sculpture Parks. Hamilton: International Sculpture Center.

Hayward, C. 2014: 'Accumulation: Sculptural Work by Alben at Gallery Nine5', www.fjordsreview.com/reviews/accumulation.html (accessed 3 February 2021).

Hughes. J. 2020: 'The Classics in Soap: An Interview with Meekyoung Shin', The Jugaad project, 22. July 2020, https://thejugaadproject.pub/home/meekyoung-shin (accessed 5 March 2021). 
Jockey, Ph. 2011: 'The Venus de Milo: Genesis of a Modern Myth', in Z. Bahrani, Z. Celik \& E. Eldem (eds), Scramble for the Past. A Story of Archaeology in the Ottoman Empire, 219-238. Istanbul: SALT.

Jungbauer, J. 2015: 'Flesh Sculptures of Everyday Object by Cao Hui'. https://www.ignant.com/2015/08/13/flesh-sculptures-of-everyday-objects-by-CaoHui (accessed 28. June 2021).

Kiilerich, B. 2006: 'From Greek Original to Modern Pastiche: the Reformulation of the Classical Statue in Contemporary Art', ActaAArtHist XX, n.s. 6: 241-65.

Kiilerich, B. 2009: 'Gamle statuer i nye værker', in M. Skoie \& G. Vestrheim (eds), Antikken i ettertiden, 240-250. Oslo: Universitetsforlaget.

Kiilerich, B. 2012: 'Venus de Milo - brug, misbrug, genbrug', Klassisk Forum 2012:2, 42-52.

Kiilerich, B. 2015: 'Michelangelo Pistolettos Venere degli stracci', Kunst og Kultur 98, 2: 84-93.

Kiilerich, B. 2018: 'Nike - fra Samothrake til Shanghai', Klassisk Forum 2018:2, 70-83.

Kiilerich, B. 2019: 'The Classical in Contemporary Sculpture: a global view', Proceedings of the Danish Institute in Athens IX: 103-113.

Kiilerich, B. 2021: 'Sovende figurer - fra antik "haveskultur" til samtidskunst, Klassisk Forum 2020:2 [2021], 36-54.

Lapatin, K. 2001: Chryselephantine Statuary in the Ancient Mediterranean World. New York \& Oxford: Oxford University Press.

Laster, P. 2021: 'Fictional Archaeology. An Interview with Daniel Arsham' 11. February 2021. www.artandobject.com/news/fictional-archaeology-interview-danielarsham (accessed 12. March 2021).

Letze, O. \& Fritz, N. 2018: Almost Alive. Hyperrealistic Sculpture in Art. Munich: Hirmer.

Marvin, M. 1997: 'Roman Sculptural Reproductions or Polykleitos', in A. Hughes \& E. Ranfft (eds), Sculpture and its Reproductions, 7-28. London: Reaktion Books.

Matelli, T. 2015: New Gravity. Davis: Davis Museum at Wellesley College. 
Meiggs, R. 1982: Trees and Timber in the Mediterranean World. Oxford: Clarendon Press.

Minnucci, R. 2020: 'Heaps of Rags and Double Visions: The Interpretation of the Classical Venus in Arte Povera', IKON 5: 361-372.

Neira, J. 2020: 'Italian Artist Fabio Viale Tattoos Classical marble Sculptures', https://designboom.com/art/Fabio-viale-tattoos-classical-marble-sculptures-04-25$\underline{2020}$ (accessed 30 March 2021).

Noorata, P. 2013: 'Artist Creates Dissected Classical Sculptures to Reveal Raw Internal Anatomy', https://mymodernmet.com (accessed 24 March 2021).

Penny, N. 1993: The Materials of Sculpture. Yale: Yale University Press.

Salmon, D. 2000: La Vénus de Milo - un mythe. Paris: Musée du Louvre.

Squire, M., Cahill, J. \& Allen, R. (eds) 2018: The Classical Now. London: Elephant Books.

Steiner, D.T. 2001: Images in Mind. Statues in Archaic and Classical Literature and Thought. Princeton: Princeton University Press.

Trione, V. (ed.), 2013: Post-classici. La ripresa dell'antico nell'arte contemporanea italiana. Milan: Electa.

Vout, Caroline 2018: Classical Art. A Life History from Antiquity to the Present. Princeton: Princeton University Press.

Witcombe, L.C.E. 2018: Eye and Art in Ancient Greece. A Study in Archaeoaesthetics. Turnhout: Brepols.

Yi Zhang Zhi 2014: Li Hongbo - A Piece of Paper. Beijing: Cathay Publishing House. 